\title{
Comparison of serum hormone levels of captive and free-living maned wolves Chrysocyon brachyurus
}

\author{
O.B. Maia1 , A.T.A. Jácomo ${ }^{5,7}$, B.A. Bringel ${ }^{2}$, C.K. Kashivakura ${ }^{5}$, C.A. Oliveira ${ }^{8}$, \\ L.O.F. Teodoro ${ }^{4}$, L. Silveira ${ }^{5,7}$, M.E.L. Teixeira da Costa ${ }^{6}$, M.C.C. Malta ${ }^{6}$, \\ M.M. Furtado ${ }^{5}$, N.M. Torres ${ }^{5}$, P.S.R. Mattos $^{3}$, P. Viau ${ }^{8}$, T.F.G. Lima ${ }^{2}$ and R.G. Morato ${ }^{1,7}$ \\ ${ }^{1}$ Centro Nacional de Pesquisa para a Conservação dos Predadores Naturais (Cenap/ICMBio), \\ Atibaia, SP, Brasil \\ ${ }^{2}$ Bet Laboratories do Brasil, Rio de Janeiro, RJ, Brasil \\ ${ }^{3}$ Centro de Pesquisa Agroflorestal (Embrapa Roraima), Boa Vista, RR, Brasil \\ ${ }^{4}$ Centro de Desenvolvimento Ambiental da Companhia Brasileira de Metalurgia e Mineração, \\ Araxá, MG, Brasil \\ ${ }^{5}$ Fundo para a Conservação da Onça-Pintada, Mineiros, GO, Brasil \\ ${ }^{6}$ Fundação Zoobotânica de Belo Horizonte, Belo Horizonte, MG, Brasil \\ ${ }^{7}$ Instituto para Conservação dos Carnívoros Neotropicais (Pró-Carnívoros), Atibaia, SP, Brasil \\ ${ }^{8}$ Laboratório de Dosagens Hormonais, Faculdade de Medicina Veterinária e Zootecnia, \\ Universidade de São Paulo, São Paulo, SP, Brasil \\ Correspondence to: R.G. Morato, Cenap/ICMBio, Av. dos Bandeirantes, s/n, Balneário Municipal, 12941- \\ 680 Atibaia, SP, Brasil \\ Fax: +55-11-4411-6633. E-mail: ronaldo.morato@icmbio.gov.br
}

\begin{abstract}
Serum hormone levels were compared between captive and free-living maned wolves and seasonal variations of sex hormones were studied. Blood samples were collected from 16 male and 26 female adult animals from Brazilian zoos, and from 30 male and 24 female free-living adults to determine serum progesterone and testosterone by radioimmunoassay. Serum testosterone concentrations varied $(P<0.05)$ across seasons for 16 captive males, being higher in autumn $(2184.7 \pm 355.1 \mathrm{pg} / \mathrm{mL})$ than in summer (1080.7 $\pm 205.4 \mathrm{pg} / \mathrm{mL})$, winter $(1270.1 \pm 276.6 \mathrm{pg} / \mathrm{mL})$ and spring $(963.9 \pm 248.1 \mathrm{pg} / \mathrm{mL})$, although they did not differ between summer, winter and spring. Testosterone concentration of 30 free-living males differed $(P<0.05)$ between autumn $(824.1 \pm 512.2 \mathrm{pg} / \mathrm{mL})$, winter $(14.4 \pm 8.0 \mathrm{pg} / \mathrm{mL})$ and spring $(151.9 \pm 90.5 \mathrm{pg} / \mathrm{mL})$. Comparison between captive and free-living animals showed no difference in autumn $(P>0.05)$. Sixteen captive males showed higher testosterone concentration during winter and spring compared with 30 free-living animals $(P<0.05)$. Progesterone concentration varied among seasons in 26 captive females $(P<0.05)$, being higher in autumn $(15.3 \pm 3.1 \mathrm{ng} / \mathrm{mL})$ than in summer $(6.6 \pm 1.5 \mathrm{ng} / \mathrm{mL})$, winter $(5.3 \pm 3.1 \mathrm{ng} / \mathrm{mL})$ and spring $(4.3 \pm 0.7 \mathrm{ng} / \mathrm{mL})$. Progesterone concentration of 24 free-living females varied between autumn $(17.1 \pm 6.0 \mathrm{ng} / \mathrm{mL})$ and winter $(1.7 \pm 0.3 \mathrm{ng} / \mathrm{mL})(P<0.05)$, but we could not obtain data for spring or summer. No difference in progesterone levels was observed between captive and free-living females in autumn and winter.
\end{abstract}

Key words: Maned wolf Chrysocyon brachyurus; Progesterone; Testosterone; Radioimmunoassay; Reproduction

Received April 13, 2007. Accepted November 13, 2007

The maned wolf Chrysocyon brachyurus is the largest canid (20-25 kg) and one of the most typical species present in the grassland areas of the Brazilian Central Highlands (1). The most significant threat to maned wolf populations is the drastic reduction of their habitat, espe- cially due to conversion to agricultural land (2). Efforts for conservation of maned wolves have resulted in the establishment of an international management plan for the development of policies to optimize captivity management (3). Captive-breeding programs may be useful for main- 
taining a population insuring against extinction. It is possible to increase the reproductive potential of the species through assisted reproductive techniques such as artificial insemination, in vitro fertilization, intracytoplasmic sperm injection, and embryo transfer, as demonstrated for other carnivore species (4). These techniques can also contribute to preserving wild species by the construction of a biological bank-containing gametes, tissues and DNA (5). Finally, assisted reproductive techniques can contribute to the establishment of gene flow between free-living and captive populations, contributing to the maintenance of adequate genetic heterozygosity (6). Fundamental knowledge of basic reproductive physiology is essential to plan and implement genome resource banking strategies that should be used in conjunction with studies on assisted reproductive techniques (7). Basic information on the reproductive-endocrine function of captive maned wolves in the Northern Hemisphere has been reported (8). However, the reproductive-endocrine characteristics of South American captive populations are unknown and there is no information on the reproductive endocrine function of freeliving maned wolf populations. Thus, our objective was to study the influence of seasonality on gonadal functions of captive maned wolves in Brazil and to compare their levels of reproductive hormones to those of free-living maned wolves.

Blood samples were collected from 42 captive adult maned wolves (16 males and 26 females) from Brazilian zoos (Parque Natural da Companhia Brasileira de Metalurgia de Mineração, Araxá, MG, N = 8; Fundação Zoobotânica de Belo Horizonte, Belo Horizonte, MG, N = 9; Zoológico Municipal de Curitiba, Curitiba, PR, $N=5$; Parque Zoológico Quinzinho de Barros, Sorocaba, SP, N = 6; Zoológico de Brasília, Brasília, DF, N = 4; Fundação Rio-Zôo, Rio de Janeiro, RJ, N = 4; Zoológico Municipal de Guarulhos, Guarulhos, SP, N = 2; Zoológico Municipal de Americana, Americana, SP, $N=4$ ). Animals were housed in pairs and fed a fruit-meat-based diet and dog food. Water was provided ad libitum. Samples were collected between June 1995 and January 1998. Samples were collected every 30 days from 16 adults between March 1996 and March 1997. Additional samples were collected opportunistically. The other 26 adults were bled on the day of vaccination against infectious diseases and 30 days post-vaccination, with additional samples being collected opportunistically every 30,60 , or 90 days. In general, for captive animals, the time elapsed from chemical restraint to blood sample collection was 3-7 min. Blood samples were also collected from 54 free-ranging adult maned wolves (30 males and 24 females) from Estação Ecológica de Jataí (21 $33^{\circ}$ 'S and $47^{\circ} 45^{\prime} \mathrm{W}$ ) and Parque Nacional das Emas (18 $19^{\circ} \mathrm{S}$ and $\left.52^{\circ} 45^{\prime} \mathrm{W}\right)$. The wolves were captured using a box-trap baited with live chickens. All free-living animals were captured in accordance with legal requirements. We were not able to determine the time elapsed between capture and blood collection for free-living animals. Samples were collected via a cephalic or saphenous vein using physical or chemical restraint (tiletamine-zolazepam, 5-10 mg/kg, Zoletil $50^{\circledR}$, Virbac do Brazil, São Paulo, SP, Brazil). Clotted blood samples were centrifuged and the sera separated and frozen within $2 \mathrm{~h}$ of collection. Sera were heated at $56^{\circ} \mathrm{C}$ for $30 \mathrm{~min}$ and stored frozen $\left(-20^{\circ} \mathrm{C}\right)$ until the time for detection of serum progesterone and testosterone by radioimmunoassay. Assays were performed in duplicate using a solid-phase ${ }^{125}$ kit (Diagnostic Products Corporation, Los Angeles, CA, USA) specific for each hormone and routinely used for domestic dogs. The sensitivity of the assay was $0.004 \mathrm{ng} / \mathrm{mL}$ for progesterone and $8.0 \mathrm{pg} / \mathrm{mL}$ for testosterone. The intra- and inter-assay coefficients of variation were $<10 \%$. Data are reported as means \pm SEM. To assess seasonality, data were averaged by season (summer: December-February, autumn: March-May, winter: June-August, and spring: September-November) and differences determined by ANOVA followed by Dunn's multiple comparison test. Samples from free-living animals were averaged by season as described above and comparisons between seasons were performed by KruskalWallis one-way ANOVA on ranks. It is important to point out that summer was not represented for free-living males and summer and spring were represented in only one sample for females and therefore were not available for this analysis. When appropriate, comparisons of samples from captive and free-living populations obtained during the same season were performed using the Mann-Whitney rank test.

Mean \pm SEM serum testosterone concentration varied across seasons $(P<0.05)$ for captive males. Testosterone concentrations were higher in autumn $(2184.7 \pm 355.1 \mathrm{pg} /$ $\mathrm{mL}$; range: $104.1-4166.6 \mathrm{pg} / \mathrm{mL} ; \mathrm{N}=19)$ than in summer (1080.7 $\pm 205.4 \mathrm{pg} / \mathrm{mL}$; range: $129.9-3136.8 \mathrm{pg} / \mathrm{mL} ; \mathrm{N}=$ 27), winter (1270.1 $\pm 276.6 \mathrm{pg} / \mathrm{mL}$; range: $21.4-4078.3 \mathrm{pg} /$ $\mathrm{mL} ; \mathrm{N}=28)$ and spring $(963.9 \pm 248.1 \mathrm{pg} / \mathrm{mL}$; range: 18.7 $3856.0 \mathrm{pg} / \mathrm{mL} ; \mathrm{N}=29$ ). Comparisons between summer, winter and spring did not reveal any difference $(P>0.05)$. Similarly, we observed a difference $(P<0.05)$ between autumn (824.1 $\pm 512.2 \mathrm{pg} / \mathrm{mL}$; range: $8.4-3515.9 \mathrm{pg} / \mathrm{mL} ; \mathrm{N}$ = 7), winter (14.4 $\pm 8.0 \mathrm{pg} / \mathrm{mL}$; range: $0.8-102.9 \mathrm{pg} / \mathrm{mL} ; \mathrm{N}$ = 13) and spring (151.9 $\pm 90.5 \mathrm{pg} / \mathrm{mL}$; range: $1.4-889.1 \mathrm{pg} /$ $\mathrm{mL} ; \mathrm{N}=10$ ) for testosterone concentration in free-living male maned wolves (Figure 1). Unfortunately, we could not capture and collect samples from free-living male maned wolves during summer. There was no difference in autumn values between captive and free-living maned 
wolves $(P>0.05)$, but captive males showed higher $(P<$ 0.05 ) testosterone concentrations during winter and spring compared with free-living animals. Progesterone levels varied among seasons in captive female maned wolves. Levels were higher in autumn $(15.3 \pm 3.1 \mathrm{ng} / \mathrm{mL}$; range: $0.83-51.5 \mathrm{ng} / \mathrm{mL} ; \mathrm{N}=29)$ than in summer $(6.6 \pm 1.5 \mathrm{ng} / \mathrm{mL}$; range: $0.4-40.0 \mathrm{ng} / \mathrm{mL} ; \mathrm{N}=31)$, winter $(5.3 \pm 1.0 \mathrm{ng} / \mathrm{mL}$; range: $0.49-19.6 \mathrm{ng} / \mathrm{mL} ; \mathrm{N}=26)$ and spring $(4.3 \pm 0.7 \mathrm{ng} /$ $\mathrm{mL}$; range: $1.0-16.4 \mathrm{ng} / \mathrm{mL} ; \mathrm{N}=34$ ), but did not differ between summer, winter and spring $(P>0.05)$. For freeliving female maned wolves, we obtained only one sample for summer and one for spring and therefore we could not compare these seasons with autumn and winter. However, levels were higher $(P<0.05)$ in autumn $(17.1 \pm 6.0 \mathrm{ng} / \mathrm{mL}$; range: $0.3-40.0 \mathrm{ng} / \mathrm{mL} ; \mathrm{N}=8)$ than in winter $(1.7 \pm 0.3 \mathrm{ng} /$ $\mathrm{mL}$; range: $0.5-4.6 \mathrm{ng} / \mathrm{mL} ; \mathrm{N}=13)$. Comparisons between captive and free-living female maned wolves did not show significant differences $(P>0.05)$ considering only autumn and winter (Figure 2).

These are the first hormonal data from free-living maned wolves. Previous behavioral and ecological studies have indicated that the free-living maned wolf is a seasonal breeder with an autumn breeding season (1), as has been described for the endocrine behavior of captive animals in both the Southern and Northern Hemispheres (8). Unfortunately, because we were unable to obtain samples from free-living females during summer and spring, we cannot draw a conclusion about the ovarian endocrine function of wild-maned wolves. Probably the failure or the low rate of capture in the summer and spring is influenced by the availability of food and maternal care, respectively. Maned wolves are omnivorous and $60 \%$ of their diet is composed of fruits, with Solanum lypocarpun representing the main fruit consumed by them (9). This fruit reaches peak production during the summer, probably affecting our capture rate. The peak of births among maned wolves occurs during the winter (1). Radiotelemetry studies have shown that during this season the mother reduces her movement area, probably spending more time with the newborn (1), a behavior that may have influenced our rate of capture during the winter. Regarding the limitations of the present study, free-living maned wolves appear to mate in autumn and births probably occur during the winter. However, it is clear that a longitudinal analysis is needed and fecal hormone analysis can help to better address this question. The gonadal activity of free-living maned wolves could be determined by closely monitoring radio-collared individuals.

Regarding the testicular endocrine function, the difficulty in capturing wild wolves did not allow us to obtain samples from the same animal year-round, thus hampering a better understanding of the influence of season on the reproductive status of free-living male maned wolves.

Captive females showed an autumn breeding season as described previously (8). Similarly, male captive maned wolves showed a peak of testosterone production during autumn, in agreement with data on testis size and sperm count (Wildt DE, Bush M, Howard J, unpublished results) previously collected from zoo animals kept in North American Zoos.

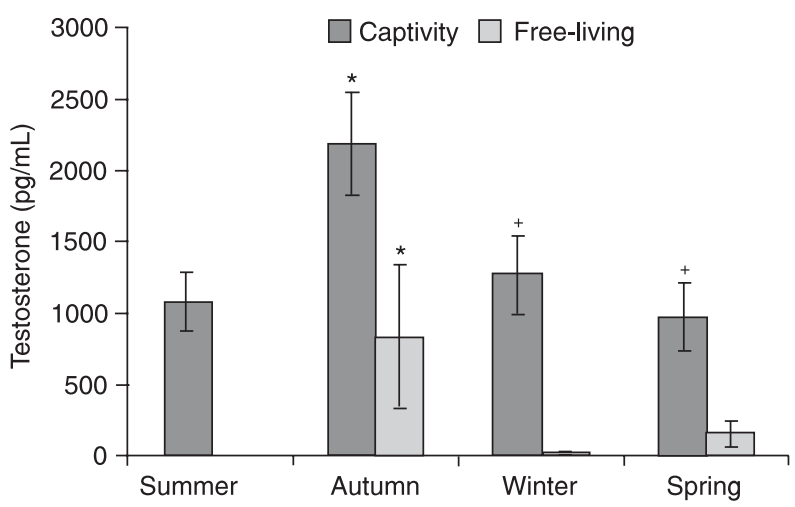

Figure 1. Seasonal variation of testosterone levels in captive and free-living male maned wolves. ${ }^{*} P<0.05$ for comparison among seasons (ANOVA followed by Dunn's multiple comparison test for captive wolves and Kruskal-Wallis one-way ANOVA test for free-living wolves). ${ }^{+} \mathrm{P}<0.05$ for comparison of captive and free-living animals (Mann-Whitney rank test). We could not obtain samples from free-living animals in summer.

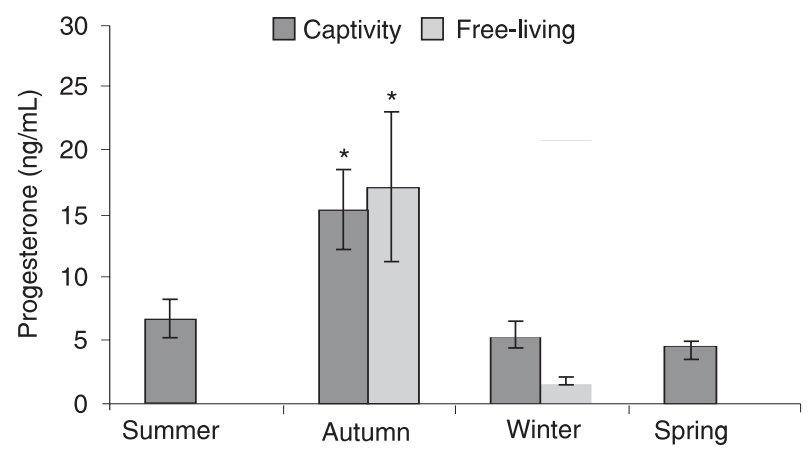

Figure 2. Seasonal variations of progesterone levels in the captive and free-living female maned wolf. ${ }^{*} P<0.05$ for comparison among seasons (ANOVA followed by Dunn's multiple comparison test for captive wolves and Kruskal-Wallis one-way ANOVA test for free-living wolves). We did not include summer and spring in the analysis of free-living animals. 
Captive maned wolves presented higher hormone levels than free-living animals during the non-breeding period. We may suggest that visual and/or olfactory contact between captive males and females can stimulate testosterone production in the male even during the non-breeding season. Exposure to females has been shown to increase circulating testosterone in rhesus monkey (10). In addition, captive maned wolves received a balanced diet throughout the year, which probably affected serum testosterone levels (11). The testosterone variation in captive males followed the pattern described here for progesterone in captive females. Similarly, within season, progesterone levels were higher in captive females $(P<0.05)$ when comparison was possible. Captive females presented a wide range of progesterone concentration even during the non-breeding seasons. In domestic dogs, levels above $2 \mathrm{ng} / \mathrm{mL}$ can represent the occurrence of ovulation (12), with progesterone concentration reaching values above $32 \mathrm{ng} / \mathrm{mL}$ in diestrous (13). Previous studies have reported some births in March, September, November, and December in the Southern Hemisphere (3), a fact that can explain the range found in the present study.

Differences between captive and free-living males may be related to the time elapsed between capture/restraint and sample collection. In captive animals, blood samples

\section{References}

1. Dietz JM. Ecology and social organization of maned wolf Chrysocyon brachyurus. Washington: Smithosonian Contribuition to Zoology; 1984.

2. Machado ABM, Martins CS, Drummond GM. Lista da fauna brasileira ameaçada de extinção. Belo Horizonte: Fundação Biodiversitas; 2005.

3. Maia OB, Gouveia AM. Birth and mortality of maned wolves Chrysocyon brachyurus (Illiger, 1811) in captivity. Braz J Biol 2002; 62: 25-32.

4. Wildt DE, Roth TL. Assisted reproduction for managing and conserving threatened felids. Int Zoo Yearbook 1997; 35: 164-172.

5. Wildt DE. Endangered species spermatozoa: diversity, research and conservation. In: Bartke A (Editor), Function of somatic cells in the testis. New York: Springer Verlag; 1994. p 1-24.

6. Morato RG, Conforti VA, Azevedo FC, Jacomo AT, Silveira $L$, Sana D, et al. Comparative analyses of semen and endocrine characteristics of free-living versus captive jaguars (Panthera onca). Reproduction 2001; 122: 745-751.

7. Brown JL, Terio KA, Graham LH. Fecal androgen metabolite analysis for non invasive monitoring of testicular steroidogenic activity in felids. Zoo Biol 1996; 15: 425-434.

8. Velloso AL, Wasser SK, Monfort SL, Dietz JM. Longitudinal fecal steroid excretion in maned wolves (Chrysocyon were obtained immediately after restraint while for freeliving animals blood samples were obtained at least $5 \mathrm{~h}$ after capture. Stress hormones are capable of suppressing testosterone concentration in males by acting along the hypothalamic-pituitary-gonadal axis (14), and the latency for a significant change in cortisol or testosterone concentration after the onset of stress is about $10 \mathrm{~min}$ (15).

Although samples were collected irregularly from each animal, combined data demonstrated a seasonal pattern and permitted a comparison between captive and freeliving animals. Thus, opportunistic blood sample collection provided valuable information related to the reproductive status of captive and free-living maned wolves.

\section{Acknowledgments}

We appreciate the collaboration of colleagues from Zôo de Brasília, Zôo de Curitiba, Zôo de Americana, Zôo de Guarulhos, Parque Zoológico Quinzinho de Barros, Fundação Rio-Zôo, Earthwatch Institute and Memphis Zoo. We are also grateful to Instituto Brasileiro do Meio Ambiente e dos Recursos Naturais Renováveis (Ibama) and Instituto Florestal de São Paulo for permitting the capture of maned wolves. brachyurus). Gen Comp Endocrinol 1998; 112: 96-107.

9. Jacomo ATA, Silveira L, Diniz-Filho JAF. Niche separation between the maned-wolf Chrysocyon brachyurus, the crabeating fox Dusicyon thous and the hoary fox Dusicyon vetulus in central Brazil. J Zool 2004; 262: 99-106.

10. Rose RM, Gordon TP, Bernstein IS. Plasma testosterone levels in the male rhesus: influences of sexual and social stimuli. Science 1972; 178: 643-645.

11. Grewall $T$, Mickelsen $O$, Hafs HD. Androgen secretion and spermatogenesis in rats following semistarvation. Proc Soc Exp Biol Med 1971; 138: 723-727.

12. Bouchard GF, Solorzano N, Concannon PW, Youngquist RS, Bierschwal CJ. Determination of ovulation time in bitches based on teasing, vaginal cytology, and ELISA for progesterone. Theriogenology 1991; 35: 603-611.

13. Badinand F, Fontbonne A, Maurel MC, Siliart B. Fertilization time in the bitch in relation to plasma concentration of oestradiol, progesterone and luteinizing hormone and vaginal smears. J Reprod Fertil Suppl 1993; 47: 63-67.

14. Cumming DC, Quigley ME, Yen SS. Acute suppression of circulating testosterone levels by cortisol in men. J Clin Endocrinol Metab 1983; 57: 671-673.

15. Sapolsky RM. Stress-induced suppression of testicular function in the wild baboon: role of glucocorticoids. Endocrinology 1985; 116: 2273-2278. 